\title{
Movements and Habitat USE OF Boreal ToAdS IN THE SNAKE RIVER QUARRY AREA
}

\author{
MARYANNE HARLOW $\uparrow$ TYLER S. HARLOW \\ UNIVERSITY OF WYOMING-NATIONAL PARK RESEARCH STATION \\ LARAMIE
}

\begin{abstract}
$\uparrow \quad$ ABSTRACT
Nine Boreal toads (Bufo boreas) were captured during the summer of 1999 at the Snake River Quarry and fitted with telemetry transmitters. Locations were determined approximately once each week. Females may be leaving the quarry site around mid-summer while males remain in the area throughout the summer. Toads preferred two aquatic sites until around mid-July then dispersed to dryer terrestrial areas with a preference for 3 sites characterized by loose soil, which provided good burrow shelter. This quarry is to undergo major reclamation efforts. It is recommended to: 1) stay major construction disturbance until the females undertake their s easonal d eparture from the a rea, 2) preserve the breeding and preferred aquatic habitat and 3) capture male toads from the preferred terrestrial areas and reintroduce them back after reclamation is completed.
\end{abstract}

\section{$\downarrow \quad$ INTRODUCTION}

The Boreal Toad (Bufo boreas) is of special interest in the Greater Yellowstone Ecosystem because it has undergone a significant decrease in the number and size of populations over the last 50 years throughout much of its range (Stebbins and Cohen 1995), including the Greater Yellowstone/Teton Area (Peterson, et al. 1992, Koch and Peterson, 1995, Koch, et al. 1996). In the eastern portion of this species' range (but not in western Wyoming) the
Boreal Toad is classified as a Candidate for Threatened and Endangered status by the United States Department of the Interior, Fish and Wildlife Service.

A population of Boreal Toads uses the Snake River quarry area in Grand Teton National Park as a breeding site. This study was undertaken to provide information to assist managers in minimizing the potential negative effects of the planned expansion and restoration activities there. The specific objectives of this study were to document the use of the Snake River Quarry area by Boreal Toads, to determine their movement patterns and habitat use of this area, and determine if and when toads use areas that will be affected by restoration and expansion activities.

\section{$\downarrow \quad$ MATERIALS AND MethodS}

\section{Study Area:}

The Snake River quarry area is located south of Flagg Ranch, about $300 \mathrm{~m}$ west of the Snake River (Map 1). It is a disturbed area, with four large waterfilled excavated quarry pits, dirt roads and piles of tailing. Temporarily flooded areas border the entry road and some of the pits. The surface of the area has been graded; topsoil and native vegetation have been largely removed. The main toad-breeding site is located at the northeast corner of the northwest pit (Map 1), where grading has created a shallow area. Some breeding also occurs in the temporarily flooded 
areas. The site is surrounded by high quality riparian and wetland habitat, with small streams and ponds, vegetated by willow, grasses and sedges.

\section{Radiotelemetry:}

BD-2G transmitters, manufactured by Holohil Systems, Ltd. (Carp, Ontario, Canada) were used to determine locations of toads during the active summer season. Transmitter frequencies included $151.081, .089, .395, .551, .581, .599, .712$ and .849 . The transmitters weigh about $1.5 \mathrm{~g}$, have a $6 \mathrm{~cm}$ whip antenna, a range of about $400 \mathrm{~m}$ and a battery life of approximately 3 months. These transmitters have been used successfully with Boreal Toads on the Targhee National Forest (Bartelt and Peterson 1994, 1996). Each transmitter was attached around the waist of the toad with a small, soft nylon belt, equipped with a wire clip that allowed the belt to come off if sufficient resistance was encountered (e.g., if the antenna "caught" between rocks or twigs).

Toads were relocated by using a Telonix Model receiver and flex antenna, at approximate weekly intervals. Each toad's location was transcribed on to a map of the area and used to describe patterns of movement and habitat use.

\section{Study Animals:}

Nine adult Boreal toads ( 6 males, 3 females) were captured at varying times between June and August. Transmitters were attached to toads for the remainder of the summer and removed prior to the onset of winter hibernation.

\section{$\uparrow \quad$ RESUlTS}

Of the nine toads that were followed, 3 were not located more than 3 times. One transmitter failed almost immediately, a raven ate one toad and one toad left the study area. The other animals were tracked successfully at least 9 times through the season (Table 1).

\begin{tabular}{|l|l|l|}
\hline \multicolumn{3}{|l|}{ Table 1. Results of tracking. } \\
\hline \hline $\begin{array}{l}\text { Toad } \\
\text { Frequency }\end{array}$ & Relocations & Comments \\
\hline .081 & 9 & Transmitter removed \\
\hline .089 & 12 & Transmitter dropped \\
\hline .397 & 8 & Moved off study area \\
\hline .551 & 18 & Transmitter dropped \\
\hline .581 & 11 & Transmitter removed \\
\hline
\end{tabular}

\begin{tabular}{|l|l|l|}
\hline .599 & 1 & Transmitter failed \\
\hline $.712 \# 1$ & 2 & Eaten by raven \\
\hline $.712 \# 2$ & 3 & Moved off study area \\
\hline .799 & 12 & Transmitter dropped \\
\hline
\end{tabular}

Transmitter \#018 was attached to a male toad on August $29^{\text {th }}$, captured at night along the service road leading to the quarry ponds. This toad was relocated 9 times between August 29 and September 17 in an extensive slash pile of logs and loose dirt approximately 200 meters southeast from its capture site (Map 2A).

Transmitter \#089 was placed on a male toad captured at night on August $3^{\text {rd }}$ along the service road within the quarry pond area. It was relocated on 12 occasions between August $6^{\text {th }}$ and September $23^{\text {rd }}$ within the same general area along the north bank of the northeast pond (Map 2B). On September $23^{\text {rd }}$ an area of approximately 10 square meters was excavated by hand. This area included about 10 dry holes in the loose soil. The transmitter was found at a depth of .5 meters within one of the holes. The transmitter was intact and could have been shed some time after August 12.

Transmitter \#397 was fitted to a male toad captured at night on August $29^{\text {th }}$ along the northern bank of the northeast pond. This toad moved east across the disturbed quarry area and was relocated on 7 additional occasions in the lower moist willow drainage and associated dryer bluff area between September $8^{\text {th }}$ and $27^{\text {th }}$ (Map 2C).

Transmitter \#551 was placed on a male toad located during the day on June $20^{\text {th }}$ in a moist drainage area that runs along the southern edge of the northeast pond and empties into the northwest pond. This toad remained in the water within the drainage from June 20 through July $3^{\text {rd }}$ and then moved eastward to a small pool near the most eastern pond (Map 2D). This pool was approximately 2 by $4 \mathrm{~m}$ and $1 \mathrm{~m}$ deep. The surrounding area was covered with thick willow stands. The transmitter signal was relocated on 14 occasions around the pond between July 13 and September $23^{\text {rd }}$. The signal appeared to be in different locations along the banks of the pond even though the toad was never directly observed. On September $23^{\text {rd }}$ the pool was almost completely dry. The banks were excavated by hand and the transmitter located within a hole about half way down the original pool depth suggesting that the toad may have remained in this area until about midAugust before shedding the transmitter. 
Transmitter \#581 was placed on a male toad located during the day of June $26^{\text {th }}$ along the western bank of the southwest pond. The toad remained in this pond within a $10 \mathrm{~m}$ stretch of the shoreline until July $2^{\text {nd }}$ and then moved to the moist drainage area along the southern edge of the northeast pond occupied earlier by toad \#551. It was relocated 4 times in this area between July $13^{\text {th }}$ and $25^{\text {th }}$. Once the drainage dried up it moved to the top of a gravel pile approximately $30 \mathrm{~m}$ wide, $70 \mathrm{~m}$ long and $10 \mathrm{~m}$ high that was located between the northeast and far east ponds (Map 2E). The top of this pile was composed of loose gravely soil and was perforated with hundreds of toad-sized holes. The toad moved from this pile down to loose gravel near the northeastern pond and then back up onto the top of the gravel pile. The transmitter was removed on August $18^{\text {th }}$ due to excessive abrasion to the hindquarters of the animal.

Transmitter \#599 was fixed to a female toad captured during the day on June 20 near the northern bank of the northwest pond (Map 2F). However, the transmitter ceased sending signals 5 minutes after the toad was released and entered the northwest pond. The toad was never recaptured.

Transmitter \#712 was first attached to a female toad on June 30 located during the day in the drainage area along the southern edge of the northeast pond also occupied by toads number 551 and 581 . The only other reading was obtained one week later on July $3^{\text {rd }}$ when the carcass was located between the northeast and northwest ponds (Map $2 \mathrm{G})$. Only the skin with the attached transmitter remained. The internal organs and muscle were not present, apparently eaten by ravens that frequented the area.

Transmitter \#712 was then attached to a female on July $3^{\text {rd }}$ captured during the day on the western shoreline of the southwestern pond. It was relocated on July $5^{\text {th }}$ but it then left the pond and was detected as a faint signal far to the north of the quarry on July $15^{\text {th }}$. This signal was only perceptible from the top of the gravel mound (Map 2H).

Transmitter \#849 was placed on a male toad captured during the day on August $2^{\text {nd }}$ in a dry hole about $15 \mathrm{~m}$ north of the northeast pond. Within a week it moved to the northern bank of the northwest pond. It then moved back to the northern dry bank area of the northeast pond on August $12^{\text {th }}$. On August $18^{\text {th }}$ it was located on the top of the gravel mound and then moved back to the dry dirt north of the northeast pond. On September $8^{\text {th }}$ it was found deep in the willows, but by September $19^{\text {th }}$ it was back on top of the gravel mound until September $27^{\text {th }}$, and then moved north to the service road on October $17^{\text {th }}$. This animal exhibited the greatest amount of movement activity of all the male toads.

\section{DISCUSSION}

Boreal Toads use the Snake River quarry area as a breeding site beginning in May and continuing to July (Koch and Peterson, 1995). Tadpoles have metamorphosed by mid-August (Peterson and Koch, 1995). The first objective of this study was to document the use of the Snake River Quarry area by adult toads. We found adults at this site from May through September. However, it appeared that females were caught primarily during the early part of summer (up until the first of July) while males were caught through August. Of the 3 telemetered females, 2 provided little data due to early predatory loss or telemetry failure. However, the one female that was tracked demonstrated a migration from the quarry site during early July. In contrast, the 6 males that were tracked remained in the study area.

A second objective of this study was to determine the movement patterns of toads and habitat use of this area, and determine if and when toads use areas that will be affected by restoration and expansion activities. Generally, toads were associated with the pond drainages during June through midJuly. Toads tended to leave these spots and were found more frequently in dry areas, burrowed into the soil from mid-July through September when the study was terminated.

Two aquatic regions of the quarry were heavily used during the early summer; 1) the drainage area along the southern edge of the northwest pond and 2) the western shore of the southwest pond.

Toads used burrows in dryer areas during later summer, which were found in 3 areas with loose soil associated with highly disturbed habitat; 1) dirt mounds along the northwest pond, 2) on top of the gravel mound located between the northeast and the far east pond and 3) loose soil in the slash pile of logs and branches west of the highway and adjacent to the entrance road.

Reclamation in this quarry site from June through August will have a profound impact on toad mortality. We recommend that such activities take 
place as late as possible in the summer, when the adult female toads have moved away from ponds and into the surrounding area. The ponds should be reconstructed over more than one season to reduce the immediate impact. Attempts should be made to preserve the aquatic areas identified as breeding sites and preferred early summer toad habitat. The areas of terrestrial use during later summer by males are primarily loose soil and gravel in disturbed habitat. As a result, no attempt is necessary to preserve these areas. However, it is recommended that effort should be made to capture male toads in these identified areas and hold them in a temporary pond until reintroduction back into the reclaimed site in order to reduce mortality to this population.

\section{$\uparrow \quad$ Literature Cited}

Bartelt, P.E. and C.R. Peterson. 1994. Riparian habitat utilization by Western Toads (Bufo boreas) and Spotted Frogs (Rana pretiosa). Final report to the USDA Forest Service Intermountain Research Station, Boise, ID. $30 \mathrm{pp}$.

Bartelt, P.E. and C.R. Peterson. 1996. Effects of grazing on the movements and habitat use of Western Toads (Bufo boreas) on the Targhee National Forest. Final report to the USDA Forest Service Intermountain Research Station, Boise, ID.
Koch, E.D. and C. R. Peterson. 1995. The Amphibians and Reptiles of Yellowstone and Grand Teton National Parks. University of Utah Press, Salt Lake City, Utah

Koch, E.D., G. Wood, C.R. Peterson, P.S. Corn. 1996. A summary of the conference on declining and sensitive amphibians in the Rocky Mountains and Pacific Northwest. Idaho Herpetological Society and U.S. Fish and Wildlife Service, Snake River Basin Office Report, Boise, Idaho. 97 pp.

Peterson, C.R., E.D. Koch, S.P. Corn. 1992. Monitoring amphibian populations in Yellowstone and Grand Teton national parks. Final report to the UW/NPS Research Center. 37 pp.

Stebbins, R.C. and N.W. Cohen. 1995.A Natural History of Amphibians. Princeton University Press. Princeton, New Jersey.

\section{ACKNOWLEDGEMENTS}

We would like to thank Dr. Chuck Peterson for use of the telemetry system and his enthusiastic guidance throughout this study. 


\section{$\underset{4}{\sim}$}

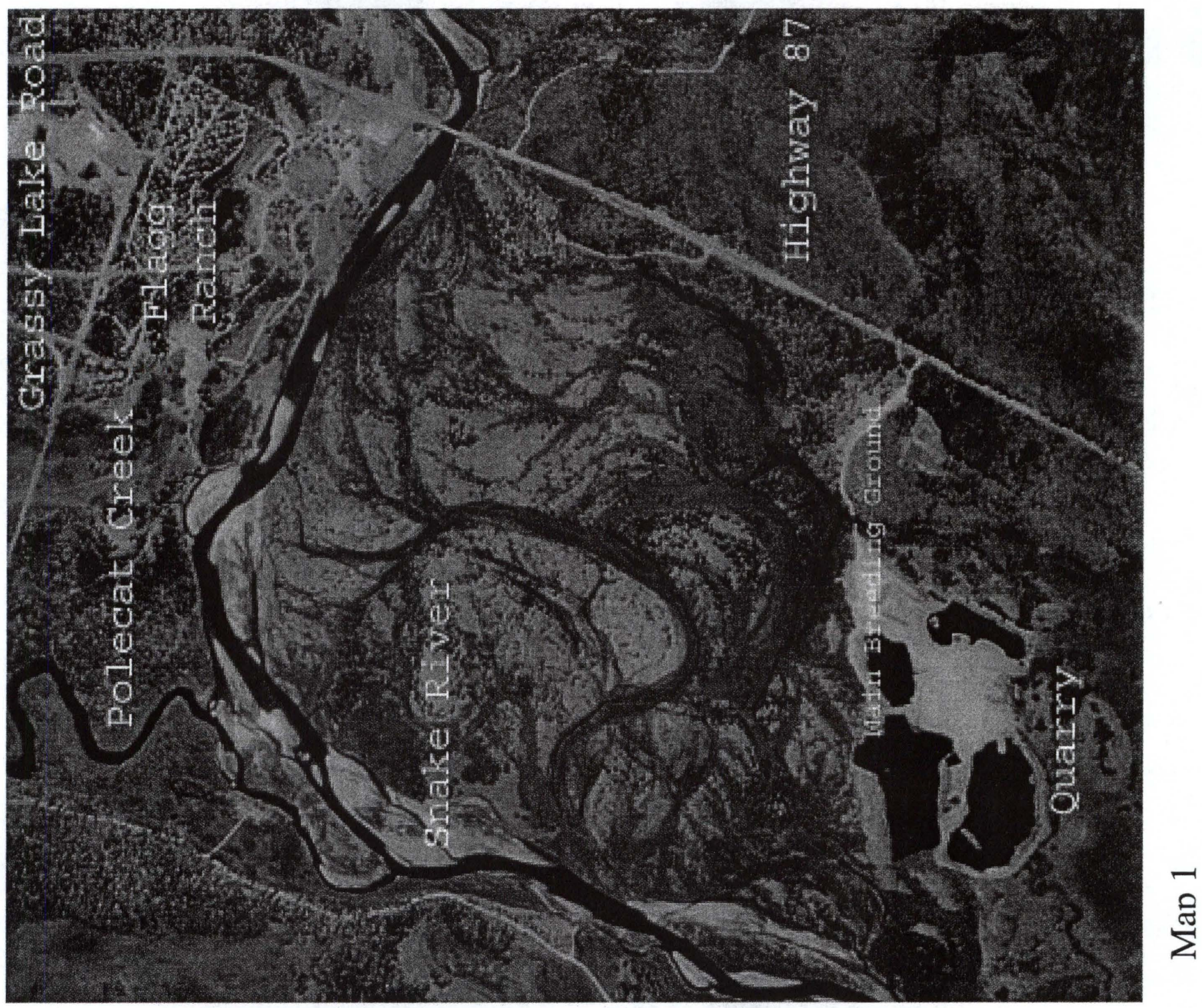




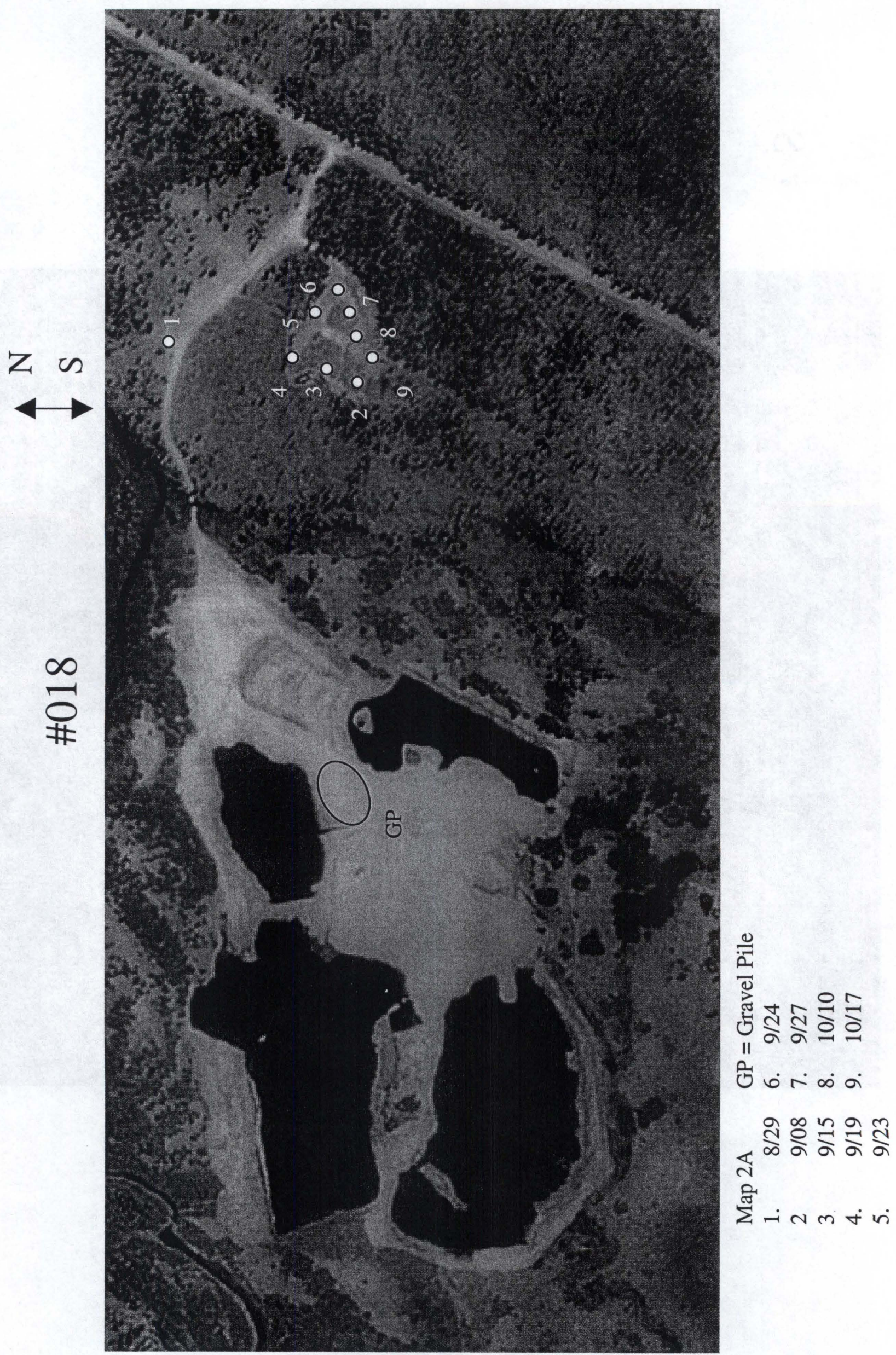




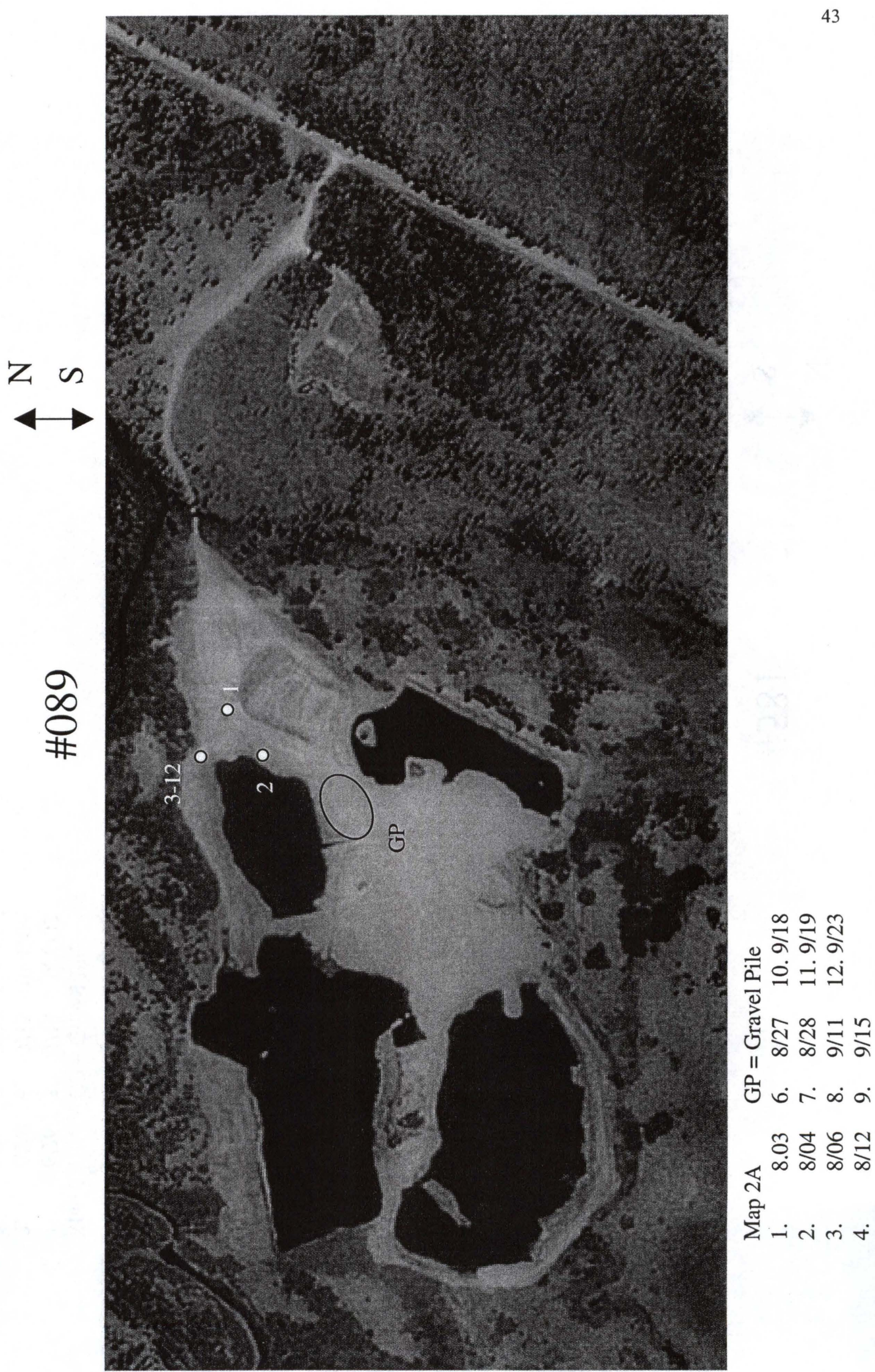


University of Wyoming National Park Service Research Center Annual Report, Vol. 24 [2000], Art. 6

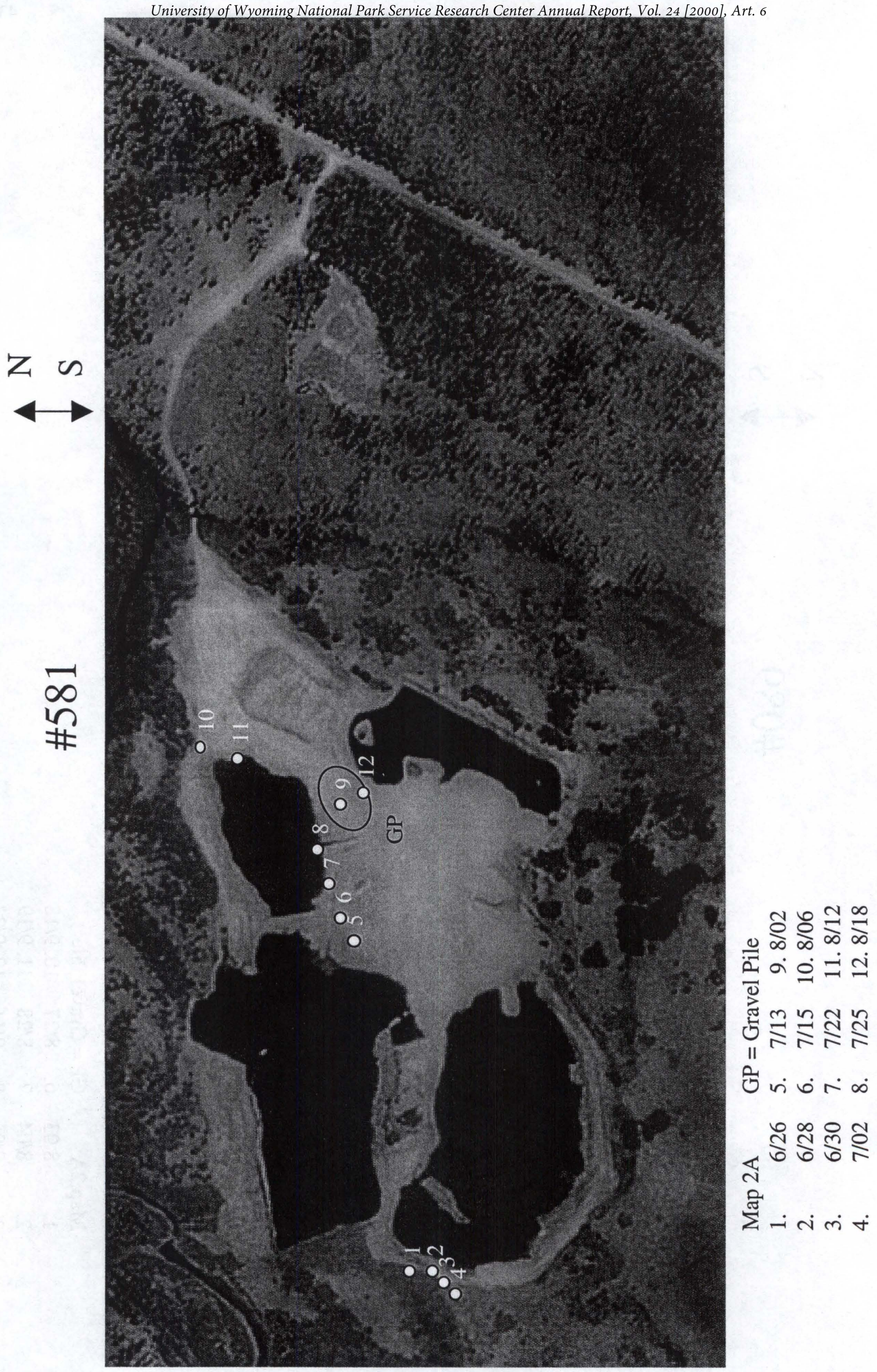




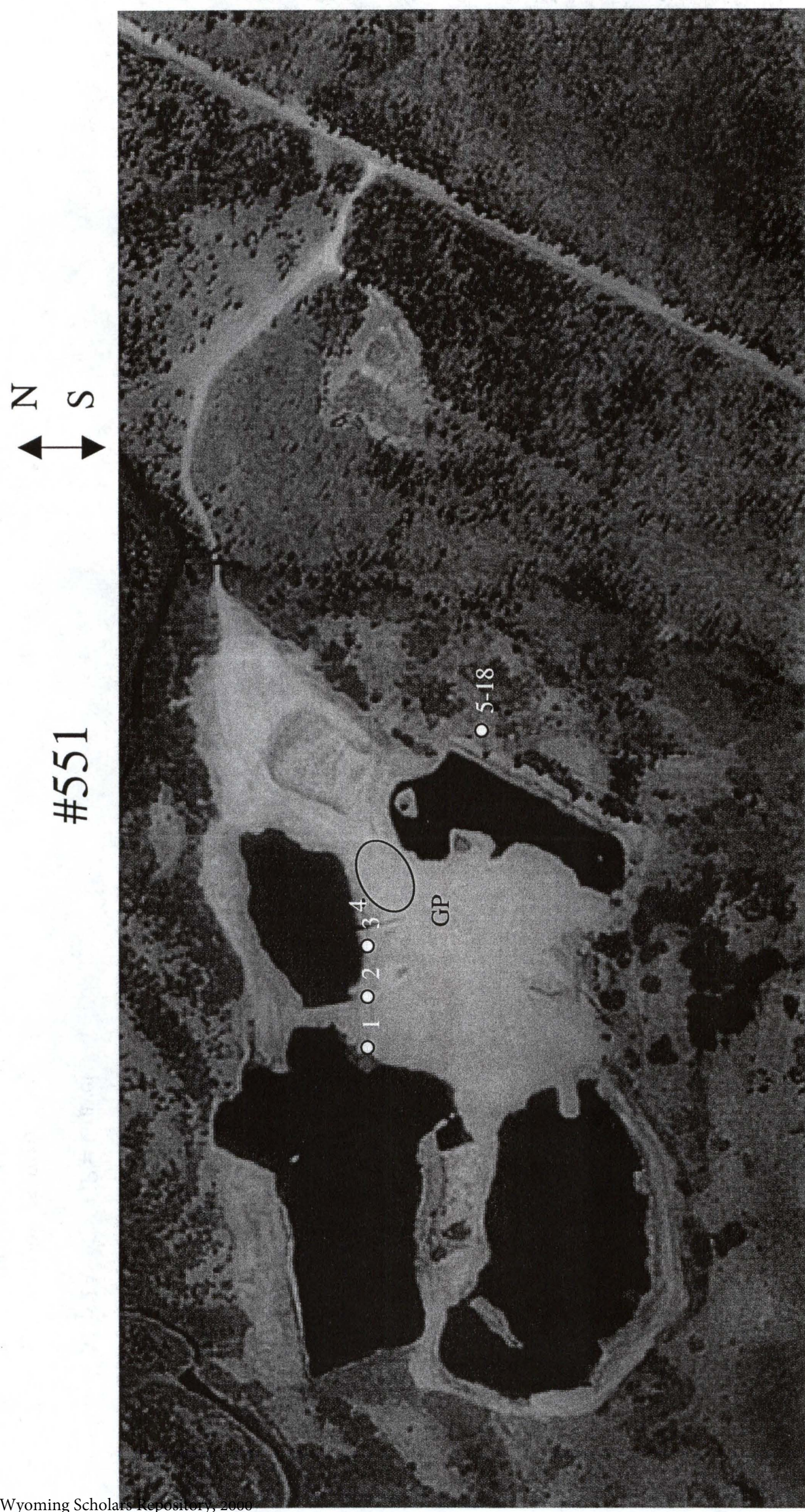

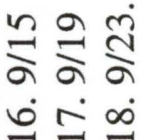

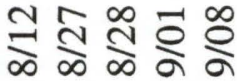
¿ 10 II

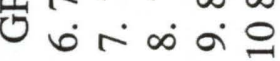

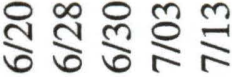

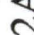

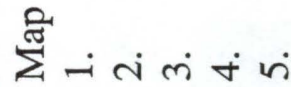




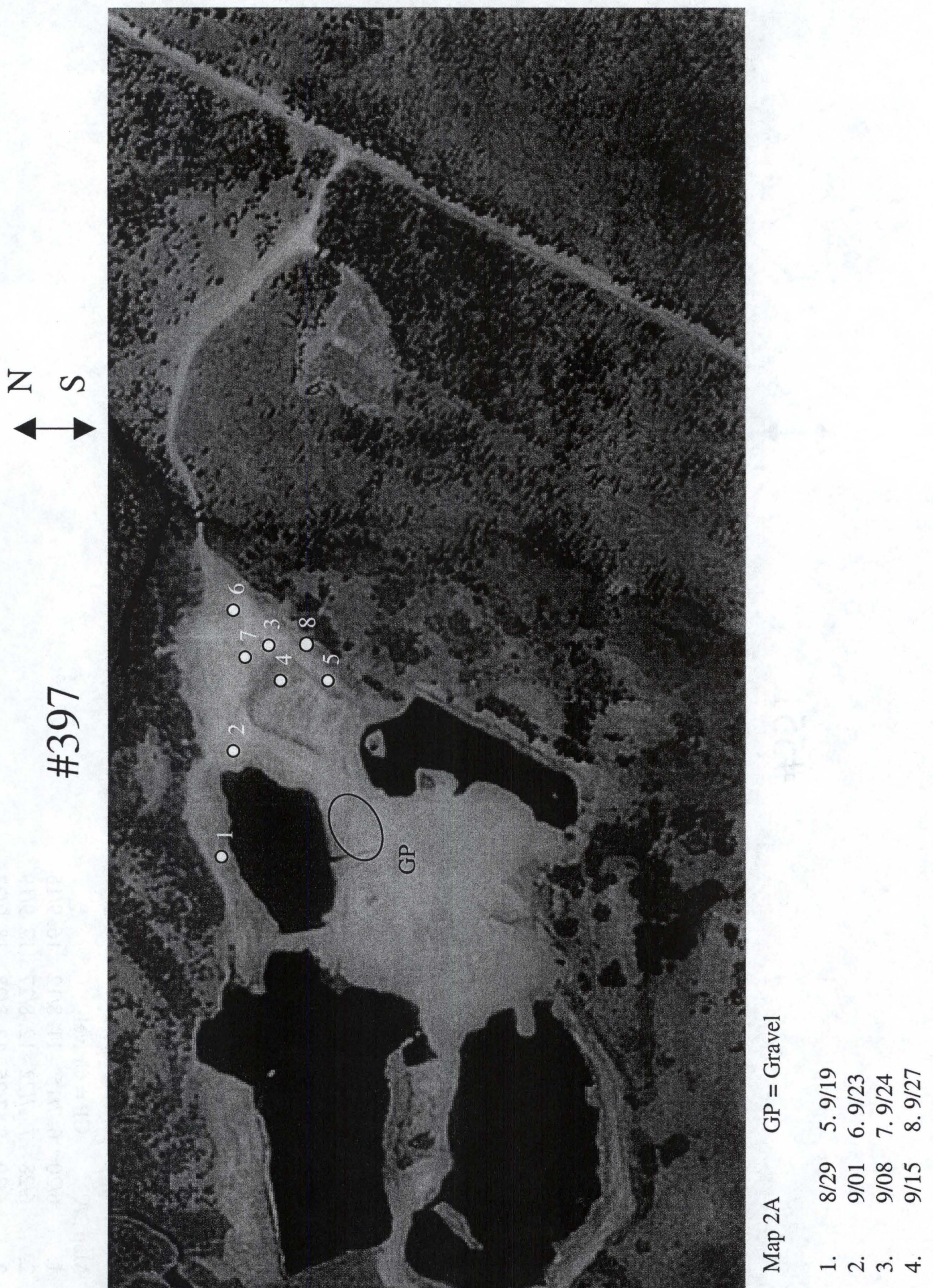




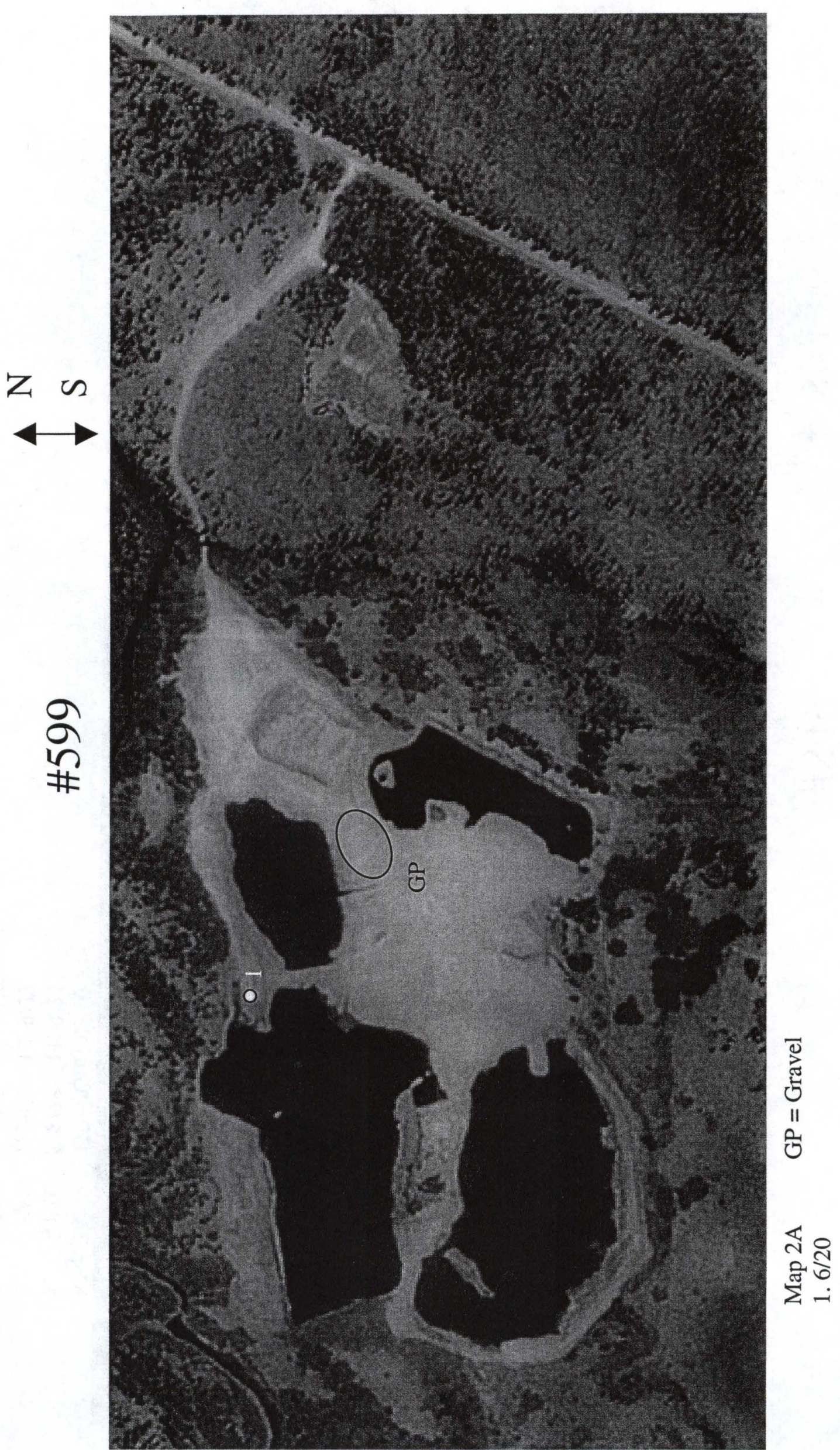



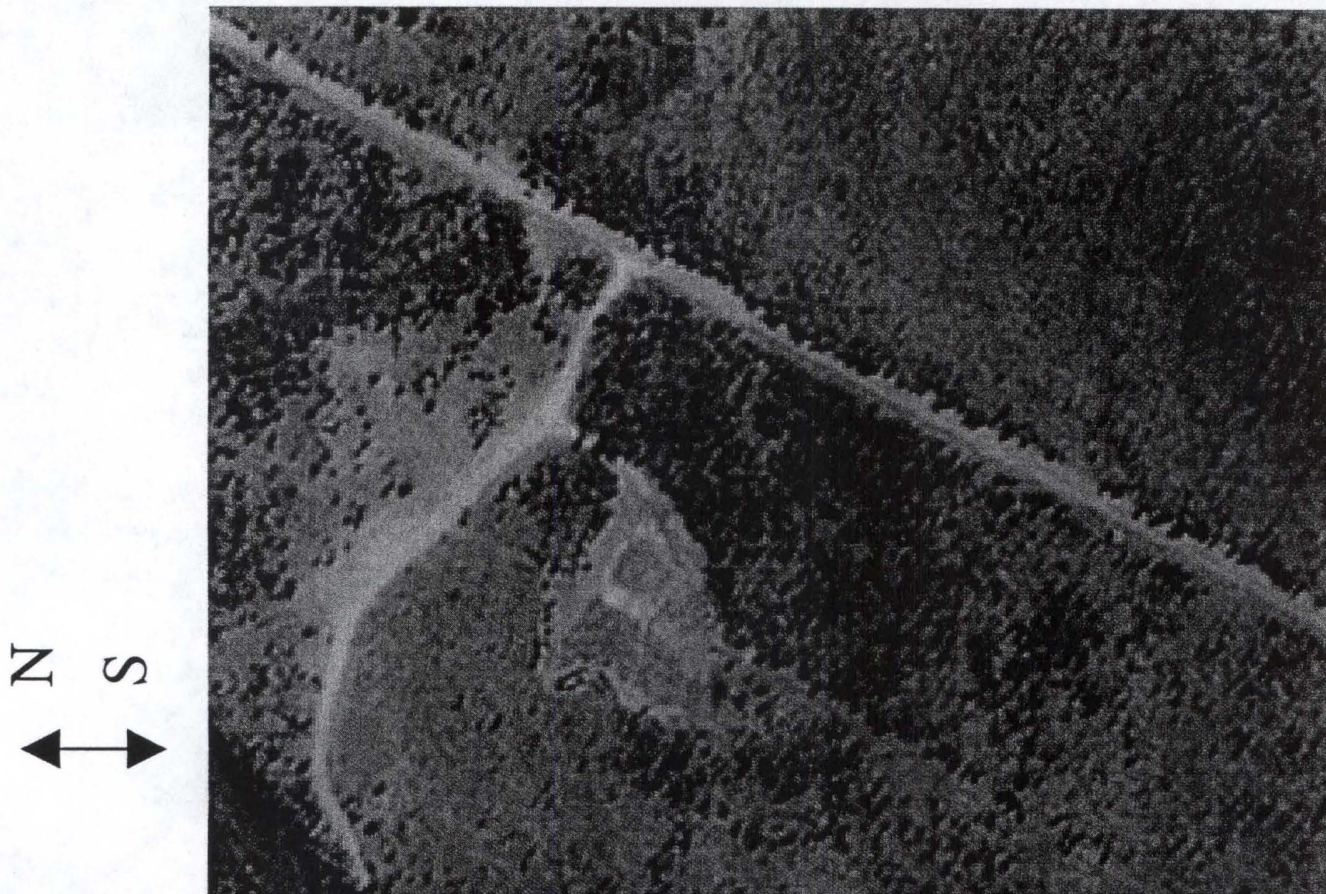

0
+
$\#$

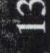

-
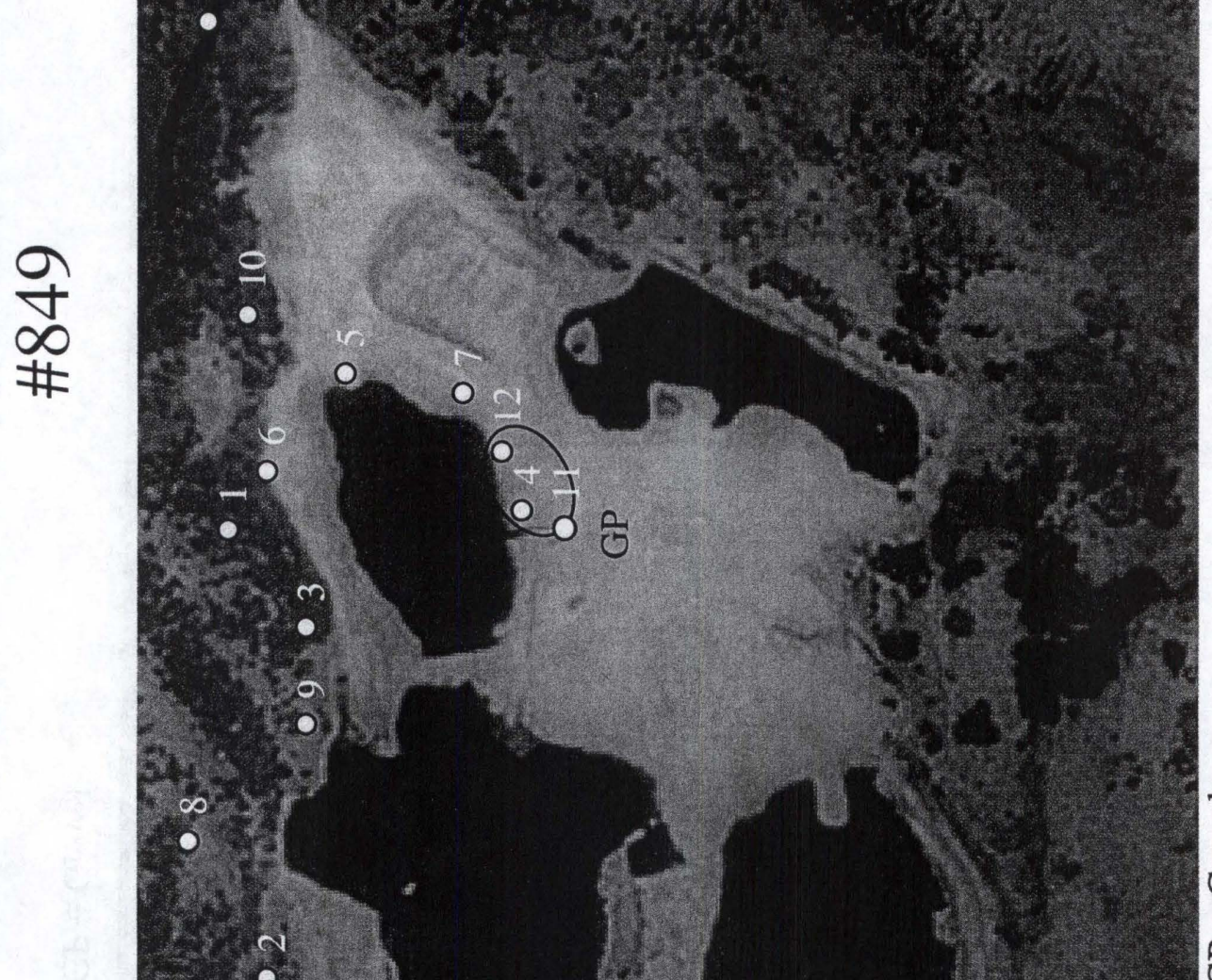

ปั

¿

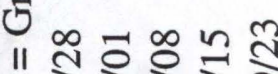

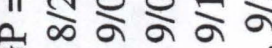
0 $\dot{\sim} \infty \sigma^{\circ}$

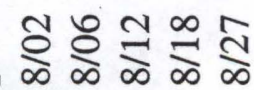
त

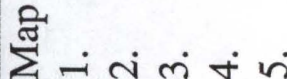




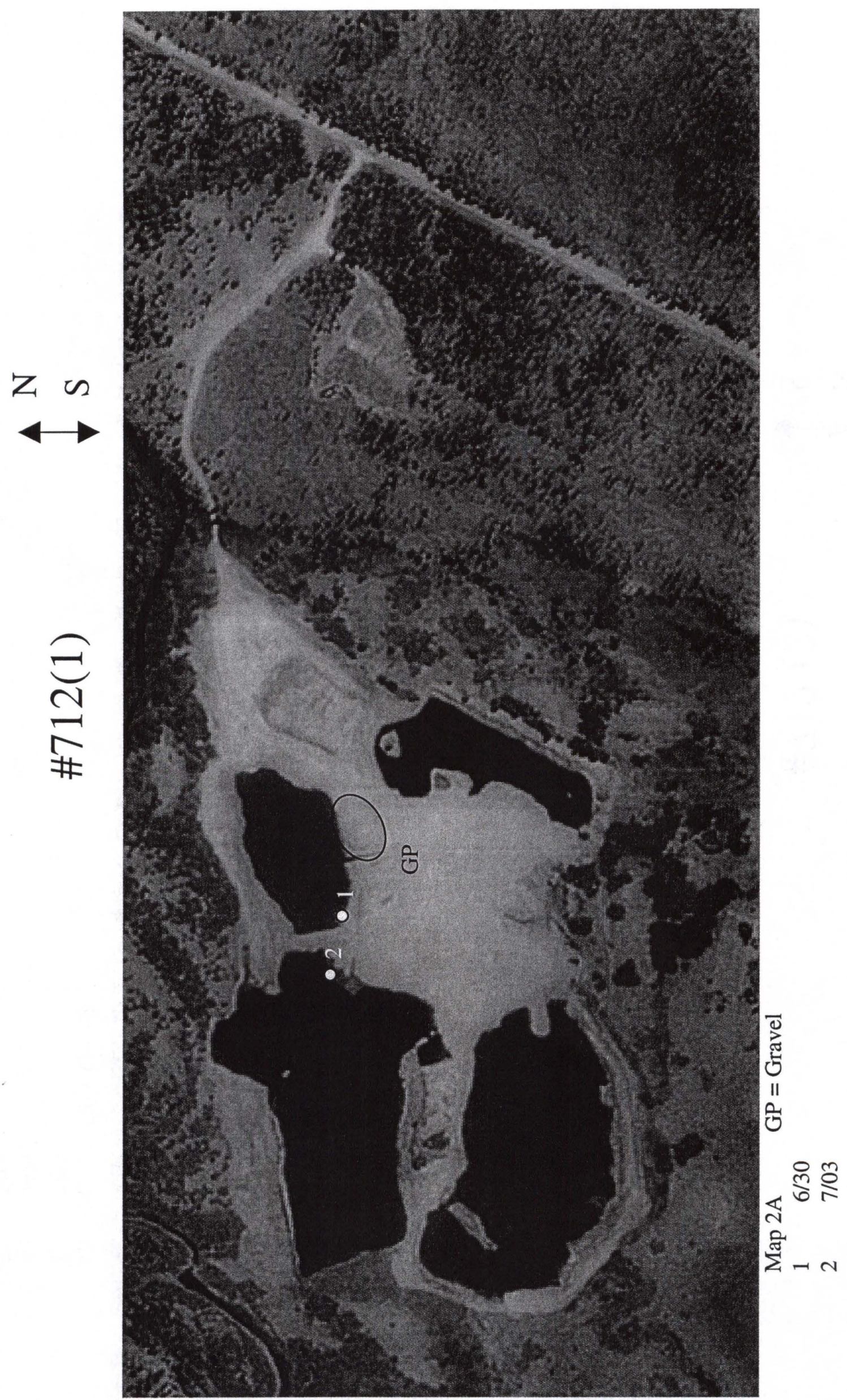




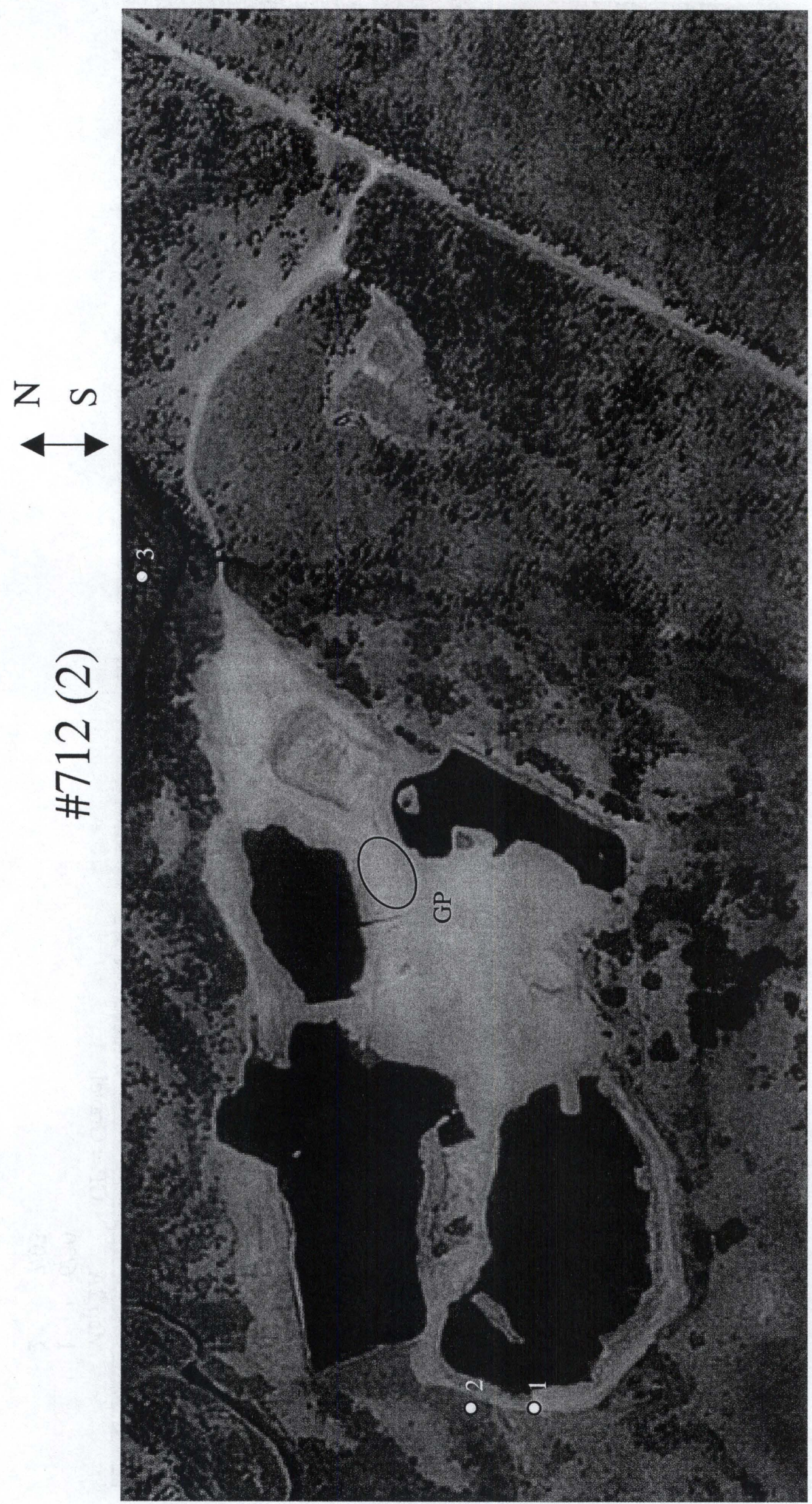

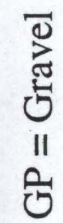

৫ํํํㅠ

त

尽 $\dot{i}$. 